\title{
Some properties of MS2-induced bacterial mutants
}

\author{
Tamara P. Pererva \\ Institute of Molecular Biology and Genetics of National Acadeny of Sciences of Ukraine \\ 150 Zabolotnogo str., 252143 , Kyiv, Ukraine
}

\begin{abstract}
Some genotype and phenotype properties of MS2-induced being granular and lysing Escherichia coli mutants are described - form of colonies, cells form and size, susceptibility to lytic agents, carbohydrates utilization, antigenic properties, Gram staining, patterns of growth and division. The numerous aberrations from wild type bacteria found in these mutants are supposed to be due not to responsible loci mutations but to accompany structural rearrangements in cell membrane components.
\end{abstract}

Introduction. We have carlier described the induction of MS2 resistant mutants developing in the offspring of an Escherichia coli A.B259 Hfr3000 (E. coli 3000) cell following this phage infection [1]. Such phageinduced mutants keep in generations the MS2-resistance marker accompanied, however, by segregation of new mutant types; some of them belong to intermediate forms, two of them being final ones [2].

The segregation of some new forms from a primary mutant strain suggests the presence of instability in a mutant cells, such a fact being a striking; feature of such mutanis comparing to spontancous ones and suggesting these forms to be phage-induced ones. Having cloned the chromosomal DNA fragment of one of these mutants on a non-replicating Apfragment [3] we were able to suppose that obtained experimental system may be used for studying of RNA phages-host intractions and possibility of some type of integration of these phages RNA or its part with $E$. coli DNA. These: investigations have been also continued using hybridization experiments with $a$ preparation of MS2 cDNA [4] and by a genetic: transfer of the mutant properties into the $\lambda$-phage chromosome [5].

This paper describes some properties of cells of two final MS2-induced mutants demonstrating that their numerous aberrations from wild type bacteria are not due to mutations having place in corresponding genes but may be connected with some: structural disturbances of mutant cell wall.

Materials and Methods. Bacterial strains. E. coli

(C) T. P. PERERYA, 1998 strains used in this study are AB259 $\mathrm{Hfr} 3000$ (E. coli 3000) (Institute of Molecular Biology, Russian Academy of Sciences, Moscow), K12 ( $\lambda$ ) and CR63 (Institute of Microbial Biochemistry and Physiology, Russian Academy of Sciences, Pushchino-on-Oka); $E$. coli CR63 $\lambda \mathrm{h}^{\mathrm{r}}$ has been obtained in our labora1ory by selection of cells resistant against $\mathrm{h}$-mutant of $\lambda$ phage.

Bacteriophages. In our experiments we worked with such phages as MS2 (Instilute of Molecular Biology, Russian Academy of Sciences, Moscow), $\lambda$ (Institute of Microbial Biochemistry and Physiology, Russian Academy of Sciences, Pushchino-on-Oka), $\mathrm{O} 2, \mathrm{O} \times 2 \mathrm{~h} 10, \mathrm{O} \times 2 \mathrm{~h} 12$ and TuIb [6] kindly providec by Prof. U. Henning; $h-$ and $h h-\lambda$-mutants were obtained in our laboratory by spontaneous mutants selection in $E$. coli CR63 and $E$. coli CR63 $\lambda \mathrm{h}^{r}$ cells, respectively. A wild type $P 1$ strain as well as T7 phage were taken from the collection of our Institute.

Culture media. Both liquid (LB) and agar-containing (LA) $(0.8$ and $1.8 \%)$ L-medium was used for bacteria growth. In some experiments our strains grew also in a liquid medium and on an agar medium containing aminopeptide (APB and APA, respectively).

Assay methods. An antiphage serum was obtained as described by Adams [7]. Electron microscopic preparations were prepared and investigated according to Bespalova et al. [8].

Results. MS2-induced mutants, both a granular and a lysing oncs, used in this investigation have been compared to an original strain, E. coli 3000 ; we have studied scveral markers such as forms of 
colonies, cells forms and sizes, their susceptibility to lysing agents, ability to carbohydrates utilization. inactivation by a serum against heated wild type bacteria, Gram staining. The data obtained have been interpretated taking into consideration two mutants growth in liquid and solid media as well as theij thermosusceptibility and auxotrophy.

Forms of colonies. $\mathrm{G}$ r a $\mathrm{n}$ u $\mathrm{l}$ a $\mathrm{r}$ t $\mathrm{y}$ p e. The colonies of this type have often more dense center: and tratnsparant wavy cdges (Fig. 1). When such colonies are kept at Petri dishes during a rather long lime they grow extensively and become branching, a part of cells growing into the agar medium. Contrary to wild type «homogenous» colonies (Fig. 2), these ones are of granular structure.

L. y s ing t y pe. The cells of this type mutant give usually colonies surrounded by lysis zone on confluent lawns formed by granular type mutant bacteria (Fig. 3). When growing on lawns of wild type bacteria lysing ones form separate colonies causing. however, no lysis. The lysing bacteria put on a usual solid medium without preformed lawn form colonies of rather contrast edges being denser comparing to wild type colonies. Those colonies are homogenous: however, during further passages a part of colonies began to form large branches of creeping growth (Fig. 4). Using the lens it becomes evident that the structure of these colonies, especially of young ones, is a little granular; however, such a granular appearance is secn only on margins of colonics, their granularity being denser comparing to granular mutants onc.

Mutant cells form and size. $G \mathrm{r}$ a $\mathrm{n} \mathrm{u} \mathrm{I}$ a $\mathrm{r} \mathrm{t} \mathrm{y}$ $p$ e $c$ e l l s. Electron microscopic investigations detect that granular type colonies (Fig. 5) contain a mixture of alive cells and of dead ones filled with lumps. A part of clead cells are non-divided filamentous forms, another cells of the same colony are markedly shortened comparing to wild type ones. A lot of cells are of curved shapes and possess spherical areas including a part of individual cell lerigth. Contrary to wild type bacteria the granular cells possess no F-pili but keep yet their flagella.

L y s ing t y p e c e I I s. Any lysing type colony contains no dead cells contrary to granular type one. So it contains no curved forms and inflations. Its cells are several times larger comparing to wild type ones, their sizes being dependent on culturc age and its cultivation conditions. Old culture without aeration contain longer non-divided forms; at the same time, young cells being in active division process present shorter forms and show a marked tendency to form chains (Fig. 6). A striking feature of lysing type cells growth is cells stiking by their side surfaces followed by conglomerations formation (Fig. 7) being evidently the cause of pellet appearance on the bottom of liquid cultures. Electron microscopic study of lysing type cells does not usually detect both $\mathrm{F}$-pili and flagella; however, some cells restore their flagella after numerous passages. Another interesting marker

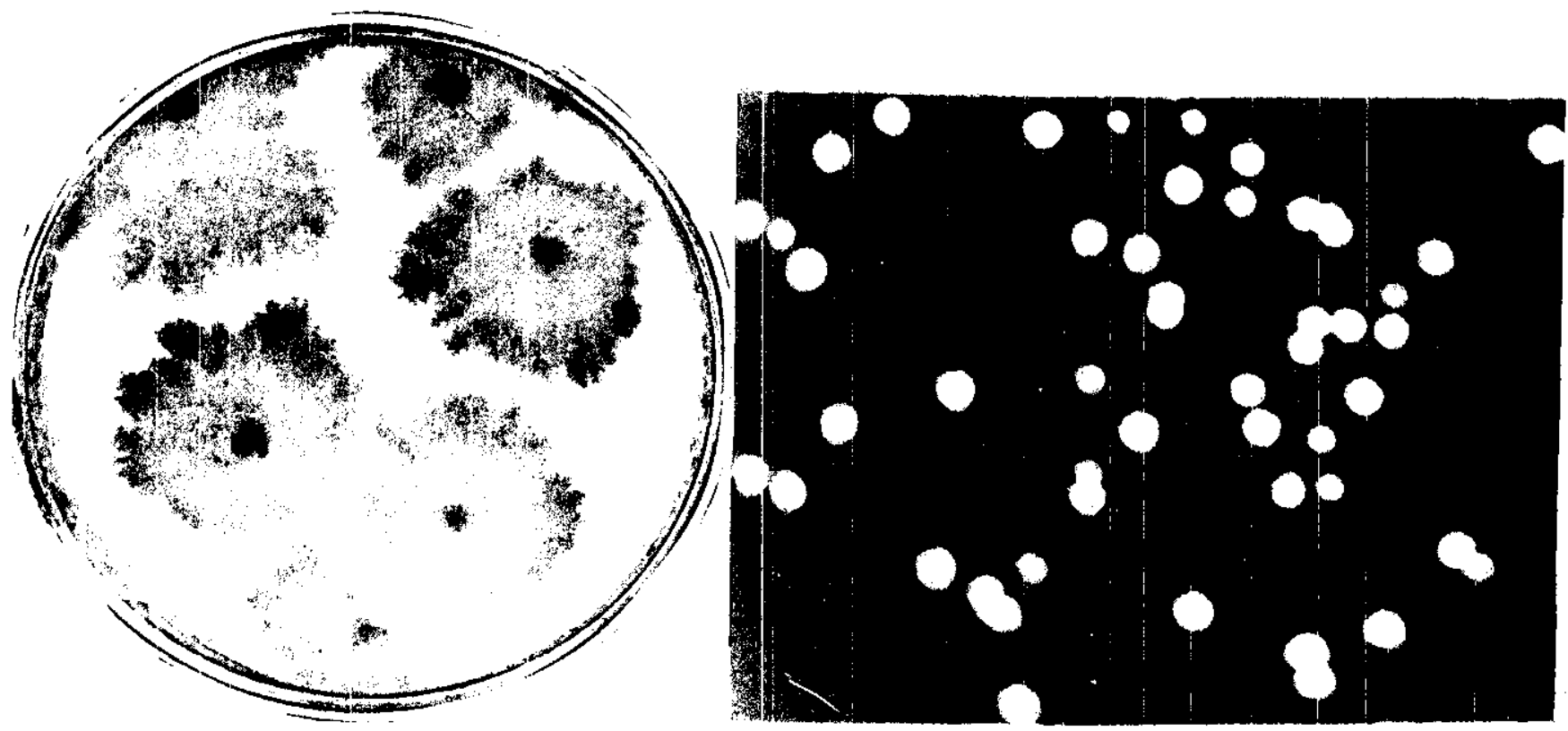

Fig. I. Colonies of a granular type mutant

lig. 2. Color ites of wild type celis 

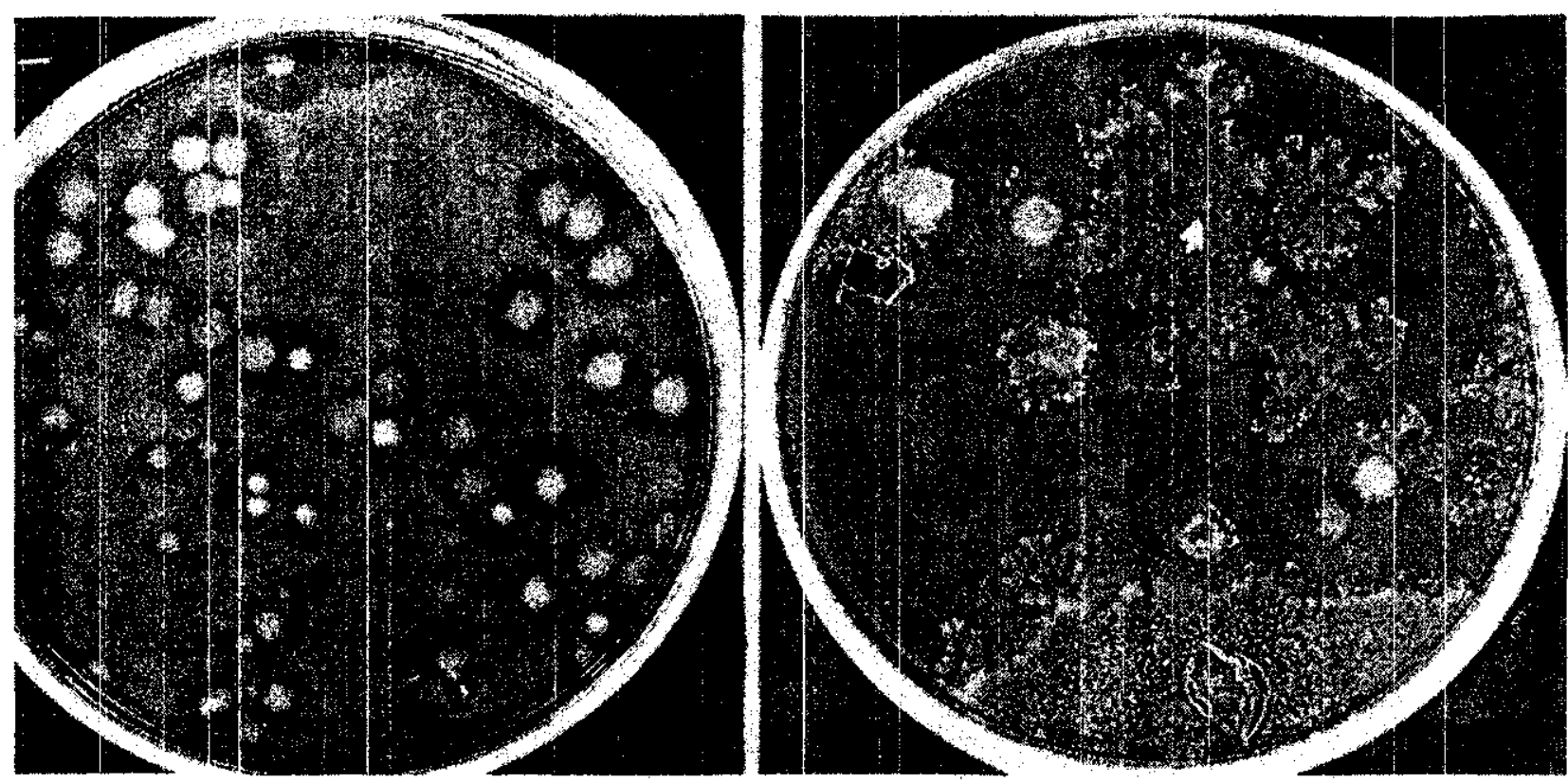

Fig. 3. Colonies of a lysing ty mutant on a lawn developed by granular type cells

Fig. 4. Colonics of a lysing type tnutant forming some branches of creeping growth

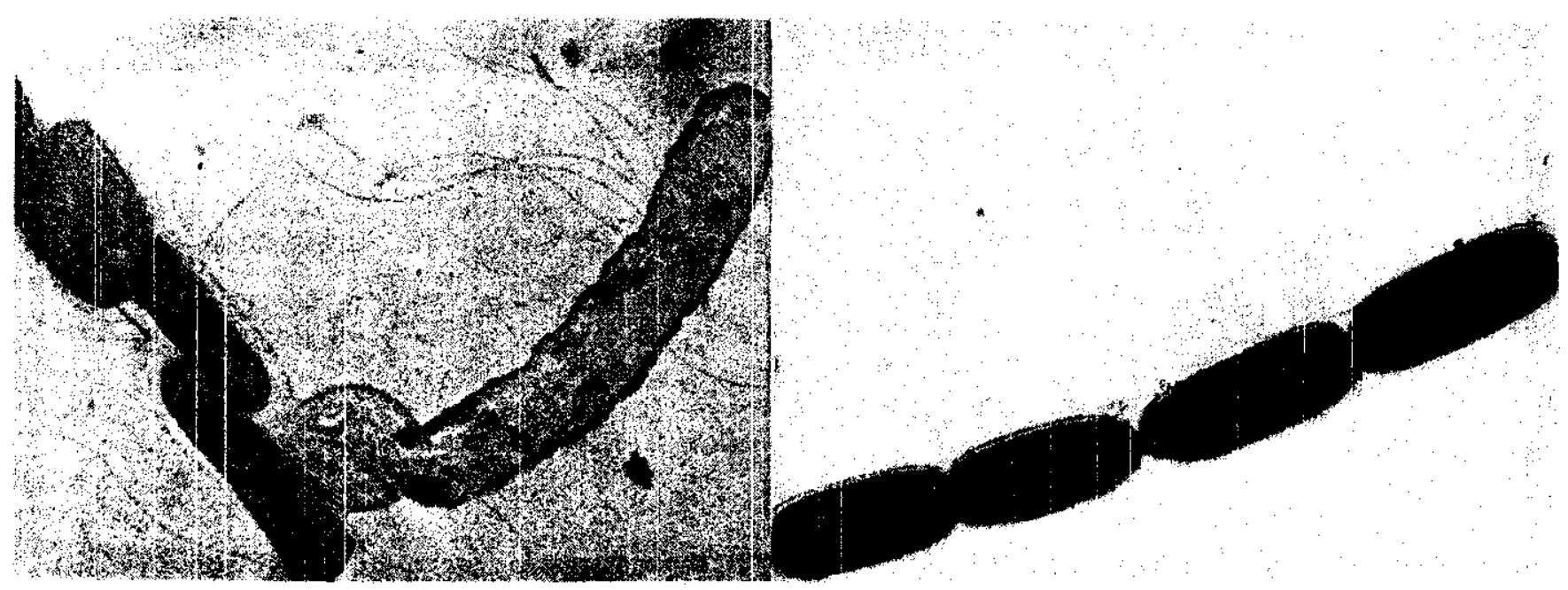

Fig. 5. Cells of a granular type mutant

Fig. 6. Chains of ct:lls formed by a lysing type mutant

found in these cells is a specific structure similar to rucleoid in actively dividing $E$. coli cells (Fig. 8).

Mutant cells reproduction in the liquid medium. Granular ty pe cel $1 \mathrm{~s}$. While cultivating in the liquid medium the granular type cells are in retard comparing to wild type ones in their growth rate and optical density level. Such a difference strikes especially if the the APB is used for bacteria cultivation, the LB medium increasing this mutant division rate and its oplical density values.
L y s ing $t$ y p e. Contrary to the granular type mutant, the lysing type one possesses growth advantages comparing to wild type bacteria. During the lag-period the mutant culture optical density values in liquid medium increase more intensively comparing to wild type cultures, the mutants transition to the stationary phase having place also at higher culture density than such a transition by any wild type culture. Besides, the lysing type cells inoculated together with wild type ones form separate colonies on 

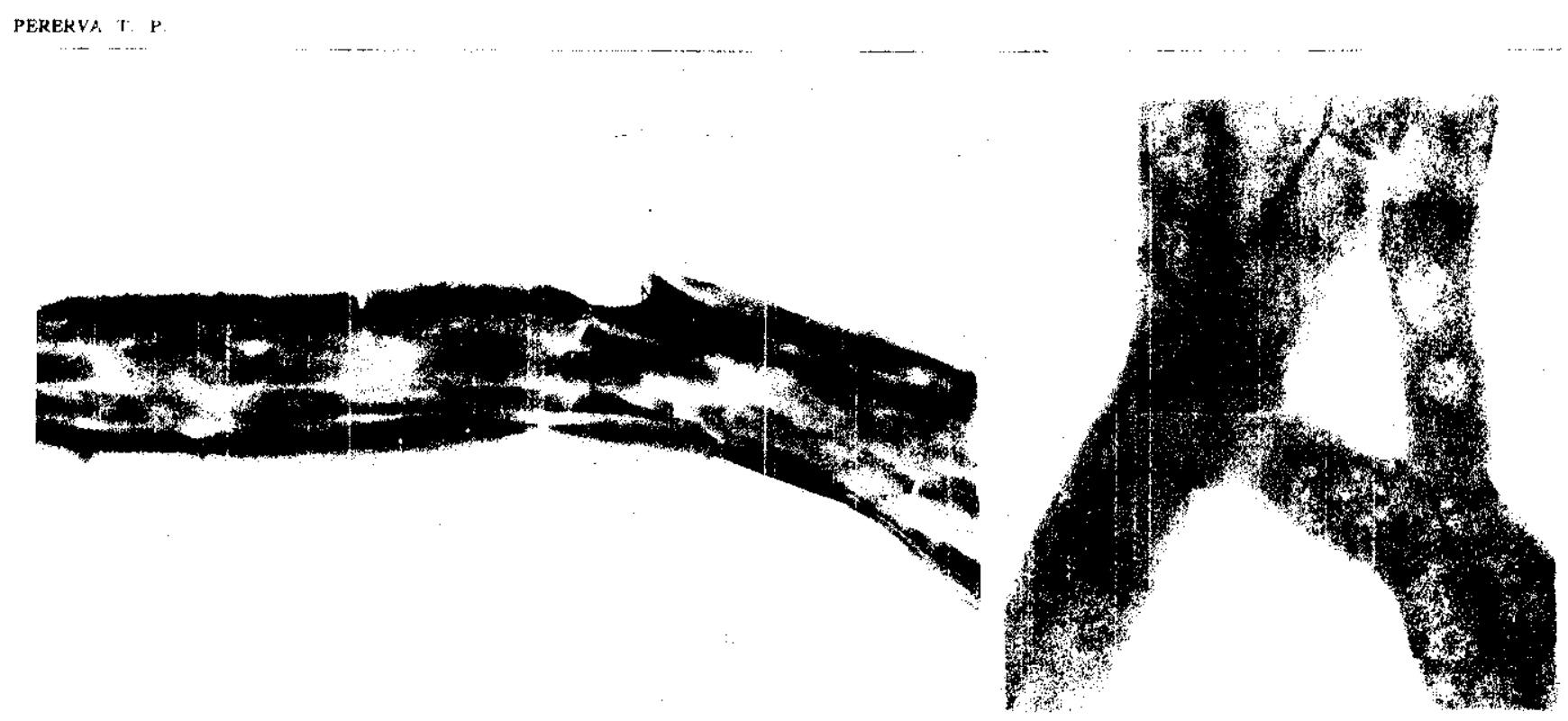

Fig. 7. Cell agglomerations of a lysing type muant

Fig. 8. Nucleoids in Iysing mutant cells

a confluent lawn of wild type cells. Such a peculiarity is a very interesting one because any other $E$. coli mutants in mixed inocula with wild type cells do not form separate colonies. The lysing mutant selective advanlage comparing to wild type bacteria correlates with its growth rate and its other growth characters in the liquid medium.

Susceptibility to lysing agents. $\quad \mathrm{G} \mathbf{r}$ a $\mathbf{n} \mathbf{l}$ a $\mathbf{r}$ $m u t$ a $n t$ c e l l s. As we have already mentioned above this mutant cells arc susceptible to a lytical agent containing by a secret of the lysing mutant. The susceptibility marker correlates with higher sensitivity to chloroform and lysozyme. The mutant cells do not grow on solid media in the area of a spot containing $0.2 \%$ chloroform. Another lysing agent, lysozyme. causes the complete cell lysis when used in concentrations necessary to obtain $E$. coli spheroplasts preparation: $0.02 \mathrm{ml}$ of $0.2 \%$ enzyme solution supplemented with $0.04 \mathrm{ml}$ of $4 \%$ EDTA are enough for the complete degradation of $10 \mathrm{ml}$ of mutant cells suspension, the cells concentration being $1 \cdot 10^{9} / \mathrm{ml}$. Besides, a part of mutant cells are lysed spontaneously while keeping in the liquid medium. The lawns formed by such mutants on the solid medium are often covered by small plaques containing no infectious phage particles.

L y s i n $g$ m u t a $\mathrm{t}$ c e l l s. These mutant cells demonstrate no increased sensitivity to lyticai substances; however, some autolysis patterns have been demonstrated in cultures having been kept too long on Petri dishes; such a phenomenon is seen because of the bacterial lawn center becoming clearer
Carbohydrates utilization. $\mathrm{G} r \mathrm{a} \mathrm{n} u \mathrm{la} \mathrm{r} \mid \mathrm{y}-$ p e c e 11 s. Such cells do not decomposc lactose, mannitol, maltose, xylose, dulcitol, rhamnose, sorbitol, and arabinose; they, however, ferment glucose up to acid product and cause also a faint sucrose fermentation.

L y s i n g m u t a $\mathrm{n} t$ c e 1 I s. Their cultures are active glucose decomposers forming the acid product during 24 hours and also of maltose and arabinose, the acid appearing on the fourth day of fermentation. All the other carbohydrates named for the granular type cells are not decomposed by the lysing mutant.

$\mathrm{G}$ r a m staining. Both granular and lysing mutant cultures are Gram-stained in a mosaic manner.

Antigenic properties. $\mathrm{G} \mathrm{r}$ a $\mathrm{n}$ u $\mathrm{l}$ a $\mathrm{r}$ t y $\mathrm{p} c$ c e $11 \mathrm{~s}$. These cells are not agglutinated by a rabbit antiserum raised against heated wild type cells, the original culture is agglutinated by the same serum diluted up to $1: 800-1: 1600$.

L y s i n g t y pe $c e^{2} 11$ s. The lysing type cells are agglutinated by the serum mentioned above diluted to $1: 50-1: 100$.

Mutants susceptibility to some coliphages. The mutants susceptibility to some $E$. coli infecting phages has been determined by the spot-test method using infectious inocula containing $10^{9}-10^{t \mathrm{j}}$ particles/ml. Both mutants have been demonstrated to be sensitive to such phages as $\mathrm{O} \times 2, \mathrm{O} \times 2 \mathrm{~h} 10, \mathrm{O} \times 2 \mathrm{~h} 12, \mathrm{Tulb}$ and $\mathrm{P} 1$ and not sensitive to $\lambda$ and $\mathrm{T} 7$ phages. Both MS2-induced $E$. coli mutants are also sensitive to $\mathrm{h}$ and hh-mutants of the $\lambda$-phage. 
Presence of conditionally lethal mutations. Both granular and lysing mutants do not demonstrate any auxotrophy or thermolability marker and form their colonies in salis-containing minimal medium and at $42{ }^{\circ} \mathrm{C}$.

Revertability. No mutant form has reverted to the original morphologic type presented by smooth nongranular colonies without lysis zones possessing standard morphology including original antigenic structure, susceptibility to coliphages, and carbohydrates utilization; sometimes, however, the sporadic flagella restoration has place by a lysing type mutant.

Discussion. The phenotypic markers of MS2induced granular and lysing type mutants describec in this paper may be divided in two groups. The firs group of markers includes Gram staining, susceptibility to lysing agents and coliphages, carbohydrate utilization, pooverty of antigens composition, complete F-pili loss and partial loss of flagella, form and sizt of mulant cells and of colonies formed by them. The second markers group concerns mutant cells growth and division propertics. The analysis of both mutan: groups permits to founc interrelations between these two groups as well as between separate odd-looking properties of MS2-induced mutants.

Among the first group mutant characters only the loss of $\mathrm{F}$-pili described in our previous papers $[1,2]$ is seeming to be due to mutational events in the region of chromosome-integrated F-factor. Development of the other mutant characters including multiple disturbance of carbohydrates utilizations can not be explained by the F-factor mutations and is probably the result of some other events.

Having used LPS-specific phages T7 and P1 we demonstrate the both mutants - the granular mutan and the lysing onc - arc resistant against $\mathrm{T} 7$ being. however, Pl-susceptible bacteria. The development of: T7-resistance suggests the disturbance of LPS structure by both mutants $[9-11]$, at least of that part of LPS which is included into forming of phage receptors on the surface of bacterial cell. As to P1 phage it is known to possess a wide host range, its bacterial receptor being a core oligosaccharide; this structure is shown to be relatively invariable by Enterobacteria.

Disturbances of LPS structure like the carbo. hydrate chains shortening may result in partial substitution of LPS by phospholipids; such a substitution increases the cell permeability for hydrophobic substances accompanied by defective cell membrane com. ponents rearrangement $[12-13]$. Some holes may' appear in this membrane dependent on the properties of such rearrangements causing mosaic Gram-staining and increased susceptibility to lysing agents. Moreover some LPS-defects such as the partial absence: of O-side chains causes cell deformations, developing of cell projections [14] and forming of R-type colonies $[15-17]$ as well as antigenic structure poorness.

The list of markers developing in MS2-induced mutants parallely with disturbed LPS forming may be supplemented also by the flagella absence in the lysing type mutant. Their sporadical restoration followed by the development of creeping growth branches seems to correlate with slight restoration of maltose and arabinose fermentation by this mutant; such a fact is in good agreement with a point of view [18] that the phosphotransferase system (PTS) responsible for the carbohydrates transport regulates also bacterial flagella proteins synthesis controlling the motility expression.

Analysing the loss of the carbohydrates utilization markers by both mutants we must take into consideration that this phenomenon is of the multiple nature; so it can be likely due to mutations having pleiotropic effect rather than to mutations in the genes encoding individual permcases and scuttered along the whole $E$. coli chromosome [19].

One of the systems theoretically capable to block the carbohydrates transport is presented by porins being the outer membrane proteins [20].

In our expcrimental system at least two main proteins of our granular and lysing mutant outer membrane - OmpA and OmpC - keep their presence and function; such a reality is suggested by mutants susceptibility to phages Ox2 (OmpA-specific receptor), $\mathrm{O} \times 2 \mathrm{~h} 10$ and $\mathrm{O} \times 2 \mathrm{~h} 12$ (specific for OmpA and OmpC proteins) as well as to Tulb (specific for OmpC) [6]. Simultaneously, the LamB function of mutant cells is damaged (absence of maltose utilization by the granular mutant, its very faint fermentation by the lysing mutant and absence of $\lambda$ susceptibility for both mutants). However, this protein. is evidently present in the outer membrane structure of both mutants judging by their susceptibility to $h$ and hh-host range $\lambda$ mutants. In such a way, the preferencial keeping of principal outer membrane proteins activities as well as scattered distribution of their coding gencs along the $E$. coli chromosome do not permit to think these genes to be responsible for the mass loss of carbohydrate utilization in MS2induced mutants.

The most marked pleiotropic effect influencing the bacterial carbohydrates metabolism is known to occur due to some defects of the carbohydrate trans fer by PTS $[18,21]$, but in our case such a presumption is little possible bccause of several reasons.

First of all, in any case of PTS mutations accompanied by the pleiotropic effect the complete 
loss of the glucose utilization marker is seen, the glucose fermentation being kept by the granular and lysing type mutants. Second, the glucose fermentation observed in our granular mutant has been never found in any $E$. coli PTS mutant.

So the analysis of the cell damages and of the carbohydrate utilization disturbancies by MS2-induced mutants made above does not permit to connect them with some mutations in the genes controlling; surface binding, proteins, outer membrane proteins. and bacterial PTS. However, the main objection against the presence of mutations in all these three genes groups is the absence of auxotrophy as well as of thermosensibility in both granular and lysing type mutants. First, such a fact does not correlate with typical propertics of mutants with damaged carbohydrate transport and utilization [21]. Second, the so-called «membrane» E. coli mutants are well-knowr to be thermosensitive (ts) ones and vice versa abou: $80 \%$ of $E$. coli ts mutants are membrane ones [13] Taking all these data irito account it is reasonable to discuss also other markers of the MS2-induced mutants and their possible dependence on cell functional damages.

The MS2-induced mutants studied here present $a$ complete system of mutants segregated from a primary MS2-resistant mutant through a series of intermediate forms $[1,2]$. The change of F-pili statc beginning from the function loss by the primaryresistant mutant up to their structural disappearance by the granular and lysing mutants accompanied by the absence of reversions in segregants permit to suggest the segregation of all the derivative forms to be due to deletions occurred in the mutant region localized in the F-factor. The aggravation of the primary mutation localized there is followed by seg. regants growth function damage becoming more faible in the granular type mutant and markedly accelerated in the lysing type mutant. The cell division process is damaged by both mutants; however, the culture of the granular type mutant contains a lot of dead filamentous cells; the culture of the lysing type mutan: is, on the contrary, presented by larger cells being alive, homogenous, and containing more than one nuclecid; such cells form often chains and conglomerations. The bacteriat growth rate and division are known to be dependent on their DNA replication controlled on the initiation level [22]. All the mutants of our experimental system originate from an $E$. coli Hfr 3000 cell carrying the F-factor integrated into the cellular DNA. In such a case the cell replication may be initiated both from the chromosomal or $i \mathrm{C}$ and from the oriF [23]. All the mutant events being deeply connected with the F-factor functions, it is possible to assert with a rather high probability the ccllular DNA replication to be initiatcd from the ori $\mathrm{F}$. According to the data concerning the levels of growth and division damages in the granular mutant as well as the nucleoids number and size in the lysing one possessing the immense DNA replication ratc accompanied by cell division retardation, the damages of or $i F$ structure and functions are very considerable.

During last two decades a lot of information was accumulated concerning the cell wall role in the DNA replication and the replicon association with membrane proteins $[24-26]$. The molecular masses of these proteins are $55-80 \mathrm{kDa}$ according to different authors [27, 28], their principal function being the bridging between DNA and outer membrane through the peptidoglycan layer. During such a bridging, a new structure appears uniting the outer cell membrane, mureine and replication origin site; such a structure regulates the DNA replication and its correlation with cell division. It is demonstrated with the $E$. coli oriC model the initiation region is to possess a specific scquence as long as $463 \mathrm{~b}$. p. to bind the membrane protein [28].

So the replication origin structure is of the greatest importance for the DNA-membrane complex formation, that is why all the mutations and structural changes occurred in the origin region of the MS2-induced mutants make such a process more difficult. The overcoming of these difficulties may, in its turn, be accompanied by damage and rearrangements of cell membranes components due to irregular localization of the large protein molecule penetrating all the cell membrane layers. The systems assuring the transport of differently directed streams of substrata and of cell metabolic products are strongly dependent on structure and function state of the cell membrane. Its defects develop a lot of aberrations similar to these ones observed for MS2-induced mutants. So the mutants described in this paper are an exellent and perspective model permitting the deepest investigations concerning the effect of the initiation region on the cell wall, cell growth and division, and total cell metabolism. Such a trend might have elaborated a new approach allowing to understand neoplastic transformation mechanism and to extend these processes modelling from lower eukaryotic organisms [29] up to prokaryotes.

Acknowledgements. The author is indebted to $\mathrm{Dr}$ S. Bobrovnik (Volodymyr Palladin Institute of Biochemistry, National Academy of Sciences of Ukraine) for electron microscopic photoes and to $\mathrm{Dr}$ Ella Zherebtsova having obtained a serum against $E$. coli cells and helped me to prepare this manuscript for publication. 


\section{T. П. Перерва}

Деякі властивості MS2-індуковағих бактеріальних мутантів

Резюме

Oписано деякі генотипьві пия фенотипові оластивості MS2 індукованих мутантів E. coli зернистово ma лізуючого типів - борма колоній, форма па об́'см клітин, чутливість д літиєних асентія, утилізаяія вуглеводів, антигенні власти зоспі, забара'т'ння по Грому' 'нециріка росту та ділення. Лрипускаспися, ио "исленні віфхилення від властивостей бакmерій дикоге тиму зумовлені ие мутаціями у відповідних ¿енах, а поз'sизані зі струкпуриок) перебудовою компонентіз клітинної мемо̆рани.

\section{T. П. Hepepoa}

Некоторье свойстиа MS2-индуцированиых бактериальньх myтантьн

\section{Резкми:}

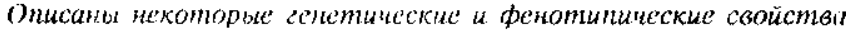
MS2-uнdуцированыох мутантов E. coli зернистого и лизируюциего типов - фрорма колониї, форма и обтем клепюк, чувствительность к литическик: асентам, утилизация углеводов, aнmихеннье свойспва, окраска по Граму, пип роста и деления. 17редnonazaется, нто многсписленные отклонения от свойсти бактерий дикого типа обусловлены не мутациями в соответ ствуюних сенах, а свнзины со структурныли перестройками

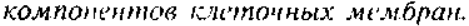

\section{REFERTNCES}

1. Перерва T. II. Устойнивость к фагу MS2, индуцированная y $E$. coli ири зараженин этим фагом // Нитология I reнетика.-1977. -11, № 1.-C. 3-9.

2. Перериа T. П., Малюmа С. С. Система MS2-индуци роганных мутантов E. coli 1ю F-фактору // Молекуляр. б̆иология ....-1984.-38.--C. $81-90$.

3. Перерва Т. П., Мирюта П. Н., Мирюта А. Ю. Лизогения у фата MS2. Cинтез фатоспецифической PHK на фаговой ДНК // Биочолимерь и клетка.-1993.-9, № 1.-С. 45-. 50.

4. Pererva $T, P_{.}$, Miriuta $\Lambda^{\prime}$. $Y_{11 .,}$ Miriuta 1. Yu et al. Lysogeny by MS2 phage. Analysis of a recombinant plasmid containing MS2 RNA-like sequence: // Taм же.--1995.-11, № 1.C. $61-65$

5. Перерва Т. ПТ., Мирюпиа А. Ю., Вудмаска М. Н., Алексеенко И. П. Јизогения у фага MS2. Экспрессия MS2.спеимфической информации сехрегантами нестабильны: трансдуцирующих фагин P'1 и $\lambda / /$ Там же.-1996.-12. No 4.-C. $73--83$

6. Morona K., Tommassen J., Henning $L$, Demonstration of a bacteriophage receptor ste on the Escherichia coli K12 outer membrane protein Omp $C$ by the use of a protease // Eur. J. Biochem. -1985.-150.--P. $161-169$.

7. Адамс $M$. Бактериосаги.-М.: Изд-во иностр. лит.$1961 .-527 \mathrm{c}$.

8. Бtспалова И. А., Крияликий А. С., Тихоненко А. С. Ufepfait T. II. Дейстние мутагенов на РНК-содержащий фar n erc PllK. VIL. Изучсние генетической природы

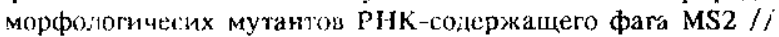
Генетика. $-1972 .-12$, \2 6.-C. $114-121$.

9. Lindberg A. A. Bactericiphage receptors // Ann. Rev. Microbiol. $-1973 .-27 .-\mathrm{P}$. 205-241.

10. Hancock R. R. W., Recves $P$. Bacteriophage resistance in
Escherichia coli K12: general pattern of resistance // I. Bacteriol.-1975.-121..P. 983-993.

11. Hancock $R$. R. W., Reeve's P. Ljpopolysacharide-deficient, bacteriophage-resistant mutants of Escherichia coli $\mathrm{K} 12$ // lbid.--1976.-127, N 1.-P. 98-108.

12. Nikaido $H$., Vaara $M$. Molecular basis of bacterial outer membrane permeability // Microbiol. Revs.-1985.-49, N 1.-P. $1-32$.

13. Braun V., Hantke $K$. Biochemistry of bacterial cell envelopes // Ann. Rev. Biochem. - 1974.-43.-P. 89--121.

14. Meadow P. M., Wells P. L., Salkinoya-Salonen M., Nurmiado E. $L$. The effect of lipopolysaccharide composition on the ultrastructure of Pseudomonas aeruginosa // J. Gen. Microbiol.-1978.-105, N 1.-P. 32-28

15. Lindberg A. A., Hellerqwist C. C. Bacteriophage altachment sites, serological specifity, and chemical composition of the lipopolysaccharide of semirough and rough mulants of Salmonella typhimurium // J. Bacteriol.-1971.-105, N 1.P. $57-64$.

16. Ornellas E. P., Stocker B. A. Relation of lipopolysaccharide character to $\mathrm{Pl}$ sensitivity in Salmonella typhimurium // Virology.-1974.-60, i 2.-P. $491-502$.

17. Poxton J. R., Sutherland J.W. [solation of rough mutants of Klebsiella aerogenes and their synthesis of polysaccharides // J. Gen. Microbiol.-1976.-96, N 1.-P. 195-202.

18. Saier H. M. Bacterial phosphoenolpyruvate: sugar phosphotransferase systems: structural, functional and evolutionary interrelations // Bacteriol. Revs. $-1977 .-41, N$ 4. - P. 856871.

19. Bachman B. Linkage map of Escherichia coli $\mathrm{K} 12 / /$ Microbiol. Revs. - 1983.-47.-P. $180-230$.

20. Benz $R$. Porin from bacterial and mitochondrial outer membranes // Ann. Rev. Biochem.- $1985 .-19, N 2 .-P .145-$ 190.

21. Гсрианович В. Н. Биохимические и генетические основы 1ереноса углеводов в бактериальную клегку--М.: Медицина, 1973.-126 с.

22. Zyskind J. W., Smith D. W. DNA replication, the baclerial cell cycle and cell growth // Cell.-1992.-69, N 1.-P. 5-8.

23. Chandler M., Silver L., Koth G., Caro L. Chromosomal replication in an Hfr strain of Escherichia coli // J. Moi. Biol.--1976.-104.--P. 517-523.

24. Sparks R. B., Irolinski $D$. $R$. Association of cellular nembrane of $E$. coli minicells with the origins/terminus region of replication of plasmid ColEl DNA // Nature.-1979.--277, N 5697.-P. 572--575.

25. Nicolaidis A. A., Holland J. B. Evidence for the specific association of the chromosomal origin with outer membrane fractions isolated from Escherichia coli // J. Bacleriol.1978.-135, N 1.-F'. 178-189.

26. Ogden G. B., Pratt $M$. J., Schaechter $M$. The replicative origin of the $E$. coli chromosome binds to the cell membranes only when hemimethylated $/ /$ Cell. $-1988 .-54 .--P .127-135$.

27. Gudas $L$. J., Janes $R$., Pardes $A . R$. Evidence for the involvement of an outer membrane protein in DNA initiation // J. Biol. Chem. - 1976.-251, N 11.-P. 3470-3479.

28. Kusuno T., Steinmetz D., Hendrickson $W$. C. et al. Direct evidence for specific binding of the replicative origin for specific binding of the replicative origin of the Escherichia coli chromosome to the membrane // J. Bacteriol.-I984.-158, N 1.-P. $313-316$.

29. Zhu J., Brun C., Kurooka H. et al. Identification and characterization of a complex chromosonal replication origin in Schizosaccharomyces pombe // Chromosoma.--1993.-102.P. 7-16.

Reccived 07.10 .97 